DOI: $10.19085 /$ journal.sijmd030501

\title{
Adam Smith, The Wealth of Nations, and the "Invisible Hand": A Metaphor For Ambiguity-Uncertainty Aversion by Decision Makers
}

\author{
Michael Emmett Brady \\ Lecturer \\ School of Business and Public Policy, Department of Operations Management \\ California State University, Dominguez Hills, Carson, California, USA. \\ OScholedge International Journal of Management \& Development (ISSN 2394-3378), Vol.03, Issue 05 (2016) pg97-102. \\ Published by: Scholedge R\&D Center [www.theSCHOLEDGE.org] [Email: editorial@thescholedge.org]
}

\begin{abstract}
Smith's use of the "Invisible Hand", as pointed out by Gavin Kennedy, is a metaphor provided for the great percentage of readers of the Wealth of Nations whom Smith realized would not be able to grasp the nature of his argument, which was about the ambiguity-uncertainty aversion of the majority of $18^{\text {th }}$ century English business men. Gavin Kennedy has pointed out that the term," Invisible Hand", had nothing to do with Laissez Faire, free markets ,free trade, Natural liberty, etc. ,for Adam Smith. Smith's argument is an application of his very advanced decision theory that regarded the standard mathematical laws of the probability calculus as a special case that had only limited applicability in the real world. In general, applications of the mathematical laws of the probability calculus required a complete information set that was rarely satisfied. Smith realized that probability, nevertheless ,had to be taken into account. Smith advocated an interval valued approach to the use of probability under conditions of uncertainty/ambiguity.
\end{abstract}

Smith made great use of the concept of uncertainty in the Wealth of Nations. Uncertainty for Smith dealt with the quality of the information base upon which the probabilities were being calculated. Smith generally defined risk in the Wealth of Nations as an inexact and/or indeterminate estimate not based on the mathematical laws of the probability calculus. Risk could be calculated exactly only in conditions where there was a very high quality of evidence over which there were no conflicts and/or disputes of assessment regarding the relevancy of the data.

Smith's major conclusion in Part IV of the Wealth of Nations is that businessmen are ambiguity and/or uncertainty averse. The quality of the information, data ,or knowledge upon which the probabilities, which would be interval estimates, is a second factor that is completely independent of the probability estimates themselves. Only in the limiting case, where the evidence is great, stable, and invariant over time, as in the case of deciding to become a shoemaker, would the probability estimates be point estimates.

Smith completely rejects the ethics and decision theory of Jeremy Bentham, as well as all approaches built on it, such as the Subjectivist ( SEU-Subjective Expected Utility) approaches of Frank Ramsey, Bruno de Finetti, L J Savage, Milton Friedman .and modern Bayesians, such as Patrick Suppes, because these approaches require the decision maker to be able to specify precise, exact numerical probabilities. The specification of such exact probabilities means that there is no uncertainty about the future. 


\section{Introduction}

Adam Smith , in earlier pages of the Wealth of Nations (WN,1776,pp.106-113,pp.226-244),had presented his inexact approach to decision making under conditions of uncertainty/risk . This led to his interval estimate approach to probability:

"The probability that any particular person shall ever be qualified for the employment to which he is educated, is very different in different occupations. In the greatest part of mechanic trades success is almost certain; but very uncertain in the liberal professions. Put your son apprentice to a shoemaker, there is little doubt of his learning to make a pair of shoes; but send him to study the law, it is at least twenty to one if he ever makes such proficiency as will enable him to live by the business... The counsellor at law, who, perhaps, at near forty years of age, begins to make something by his profession, ought to receive the retribution, not only of his own so tedious and expensive education, but of that of more than twenty others, who are never likely to make any thing by it." (Smith,1776,pp.106-107; underscore by author).

Only the shoemaker occupation problem can be analyzed using precise numerical probabilities. The uncertain lawyer problem requires the use of interval valued probabilities because of the insufficient amount of relevant evidence upon which to base the probabilities.

Adam Smith gave a very clear, precise, and concise definition of the term uncertainty in the Wealth of Nations that has been overlooked for 240 years:

" That of the Yorkshire cloth, which is made altogether of English wool, is said, indeed, during the course of the present century, to have fallen a good deal in proportion to its quality. Quality, however, is so very disputable a matter, that I look upon all information of this kind as somewhat uncertain. “(Underline added by author )(Smith,1776, p.244)

Smith had also stated that uncertainty comes in degrees:

"The certainty of what each individual ought to pay is, in taxation, a matter of so great importance, that a very considerable degree of inequality, it appears, I believe, from the experience of all nations, is not near so great an evil as a very small degree of uncertainty."(Smith,1776, p.778).

We can summarize Smith's contribution so far. Uncertainty is epistemological. It is different from the mathematical concept of risk associated with the probability calculus. A decision maker must use inexact, interval valued probabilities in the real world. The mathematical theory of probability is limited in its application to decisions where the decision maker has a great deal of relevant evidence ,which is stable and invariant overtime .

Finally, Smith realized that in many cases the relevant evidence underlying and supporting the probability assessment was vague, unclear and conflicting. Exact or determinate probability estimates were not possible. However, inexact or indeterminate estimates of probabilities were possible:

"The value of the risk, either from fire, or from loss by sea, or by capture, though it cannot, perhaps, be calculated very exactly, admits, however, of such a gross estimation, as renders it, in some degree, reducible to strict rule and method. The trade of insurance, therefore, may be carried on successfully by a joint-stock company, without any exclusive privilege. Neither the London Assurance, nor the Royal Exchange Assurance companies have any such privilege."(Smith,1776 ,p.714,author's underscore and emphasis). 
The following two sections will analyze Smith's Ellsberg like contrast of two possible choices ,one choice being the domestic trade option and the other choice being to engage in foreign trade. Keynes's later emphasis on the weight of the evidence, $w$, where $w$ is defined on the unit interval $[0,1]$, in decision making in his analysis that was presented in the A Treatise on Probability in 1921 in chapters 6 and 26 underlies Smith's analysis. We will present our conclusions in the last section .

\section{Adam Smith, Decision theory, and the Invisible Hand}

Consider Smith's argument leading up to his use of the Invisible Hand:

"Thus, upon equal, or nearly equal profits, every wholesale merchant naturally prefers the home trade to the foreign trade of consumption, and the foreign trade of consumption to the carrying trade. In the home trade, his capital is never so long out of his sight as it frequently is in the foreign trade of consumption. He can know better the character and situation of the persons whom he trusts; and if he should happen to be deceived, he knows better the laws of the country from which he must seek redress."

The uneasiness, however, which he feels at being separated so far from his capital, generally determines him to bring part both of the Koningsberg goods which he destines for the market of Lisbon, and of the Lisbon goods which he destines for that of Koningsberg, to Amsterdam; and though this necessarily subjects him to a double charge of loading and unloading as well as to the payment of some duties and customs,... . yet, for the sake of having some part of his capital always under his own view and command, he willingly submits to this extraordinary charge;. He saves himself the risk and trouble of exportation, when, so far as he can, he thus converts his foreign trade of consumption into a home trade.

He generally, indeed, neither intends to promote the public interest, nor knows how much he is promoting it. By preferring the support of domestic to that of foreign industry, he intends only his own security; and by directing that industry in such a manner as its produce may be of the greatest value, he intends only his own gain; and he is in this, as in many other cases, led by an invisible hand to promote an end which was no part of his intention.'(Smith,1776,pp.421-423)

Smith's position, that

"He can know better the character and situation of the persons whom he trusts; and if he should happen to be deceived, he knows better the laws of the country from which he must seek redress, and... for the sake of having some part of his capital always under his own view and command ...",

is that the businessman has more reliable knowledge, information and data in the domestic trade than in foreign trade.This has nothing to do with risk, which Smith discusses later in the quotation above. Smith's assessment is identical to Keynes's discussion and application of the weight of the evidence, $w$, in chapter 26 of the TP in his conventional coefficient of risk and weight ,c. Any discussion of weight automatically brings in nonlinearities and non additivity into discussions of decision theory.

Smith's analysis of decision making under uncertainty/ambiguity ,as opposed to risk, is summed up in his use of the term, "Invisible Hand", on p.423 of the WN. Smith, as correctly pointed out by Gavin Kennedy (see references), used the "Invisible Hand" term as a metaphor to help readers who could not grasp the concept of decision making under uncertainty/ambiguity,where differences in the completeness of the knowledge base are extremely important ,as opposed to risk ,to come to some type of understanding of his analysis. Smith used the term here because he knew that it was practically certain that none of his readers would be able to grasp the uncertainty versus risk concept. 
The problem facing the decision maker on pp.421-423 of the $\mathrm{WN}$ is whether to invest in the relatively certain domestic trade, which had a very high weight of evidence a la Keynes to support the probability estimates, or to invest in the foreign trade, which had a very low weight of evidence, a la Keynes, supporting it and was highly uncertain. The probability estimates would have to be intervals in the case of the foreign trade option. The decision maker would have to concentrate on the lower bound of the interval.

This two option problem is very similar to the shoemaker -lawyer problem, which is also an Ellsberg Paradox type problem very similar to Ellsberg's first problem of two urns, one with 50 red and 50 black balls and the other with a total of 100 red and black balls, but with no knowledge of the number of red and black balls. The first urn is the risky urn that around $75 \%$ of decision makers in various test situations over the last 55 years prefer to draw from while the second urn is the ambiguous or uncertain (lack of weight urn according to Keynes from chapters 6 and 26 of the TP) urn that around $20 \%$ of decision makers prefer to draw from.5\% are indifferent. This $5 \%$ figure is the correct answer according to SEU theory because the amount and quality of the evidence should play no role in the elicitation of subjective probabilities according to Ramsey, de Finetti, Savage, and Milton Friedman.

Smith realized that the majority of business decision makers would prefer the domestic trade, as opposed to the foreign trade, because of the far greater evidentiary support available upon which to assess probabilities in the domestic trade .However,some decision makers prefer ambiguity and uncertainty .These decision makers would choose the foreign trade, which, as Smith pointed out ,would require the use of indeterminate probabilities:

"The value of the risk, either from fire, or from loss by sea, or by capture, though it cannot, perhaps, be calculated very exactly, admits, however, of such a gross estimation, as renders it, in some degree, reducible to strict rule and method. The trade of insurance, therefore, may be carried on successfully by a joint-stock company, without any exclusive privilege. Neither the London Assurance, nor the Royal Exchange Assurance companies have any such privilege."(Smith, 1776, p.714, author's underscore)

Of course, this indeterminate risk would not have to be dealt with at all by decision makers choosing the home trade. Note that Smith's risk concept in the above quote refers to the risk of operating in an uncertain environment or decision atmosphere and has nothing to do with the concept of risk as used by Classical , Neoclassical, and modern economists, which is tied in to the standard deviation .

The term,"Invisible Hand", allows a reader of the WN ,who would have no understanding of Smith's very advanced decision theory, to feel that he /she had understood the conclusion Smith had reached, if not the technical nature of the analysis presented by Smith , which is 150 years ahead of his time.

\section{Smith and Microeconomic Theory}

Smith's mastery of the uncertainty versus risk distinction means that he rejected the standard microeconomic theory of his day because the microeconomics of his day allowed no role for the uncertainty versus risk distinction to play in the determination of prices, demand for money, liquidity preference, or fixed capital.

For example, consider again the following analysis of Smith:

“...though this necessarily subjects him to a double charge of loading and unloading as well as to the payment of some duties and customs, yet, for the sake of having some part of his capital always under his own view and command, he willingly submits to this extraordinary charge...".

The ambiguity averse merchant is willing to pay a premium to increase the weight of the evidence , $w$,, which increases his confidence in his decision making capability. This increase in confidence on the 
part of the business man leads him to increase his investment in the home country, which benefits as a result due to the increased employment and income streams that arer generated.

Work done over the previous two centuries by economists on Smith's microeconomics will need to be revised and completed in order to satisfactorily incorporate an account of the rolethat uncertainty plays in Smith's application of the uncertainty versus risk difference to the shoemaker-lawyer problem and the domestic trade-foreign trade problem

\section{Conclusions}

The Invisible Hand metaphor refers to the fact that ambiguity averse business men will choose the home/domestic market because it is less risky and far less uncertain than the Foreign markets .Their confidence will be increased.This means that there will be more spending, investment, employment, and economic growth in the home market because the majority of merchants will invest in the home market to avoid the uncertainty of the foreign markets. They will not have to worry about their ships sinking in storms or raids on their merchant ships by pirates.

\section{References}

Bentham, Jeremy .(1789).Defense of Usury. Kessinger Publishing,pp.1-74.

Bentham, Jeremy,(1787).The Principles of Morals and Legislation. Nabu Press. NY;NY.

Buchan, James (2006). The Authentic Adam Smith: His Life and Ideas. New York: W.W. Norton and Company.

Ellsberg, D. (2001).Risk, Ambiguity and Decision (Studies in Philosophy).England: Routledge

Keynes, J. M. (1921). A Treatise on Probability. The Collected Writings of John Maynard Keynes

(CWJMK) vol. VIII. London: Macmillan, 1973.

. F. P. Ramsey. In Essays in Biography, CWJMK (pp. 335-346), vol. X, London: Macmillan for the Royal Economic Society (reprinted from The New Statesman and Nation, 3 October 1931).

Keynes, J.M. (1921). A Treatise on Probability. London: Macmillan.

Kennedy, Gavin (2009). "Adam Smith and the Invisible hand: From Metaphor to Myth", Economic Journal Watch,Vol.6,no.2,May,pp. 239-263.

Kennedy ,Gavin (2012).The Myth of the Invisible Hand-A View from the Trenches. Paper presented at the $44^{\text {th }}$ Annual UK History of Economic Thought Conference-Keele University, 4 September 2012.

Klein, Daniel B. (2009)."In Adam Smith's Invisible Hands: Comment on Gavin Kennedy", Economic Journal Watch,Vol.6,no.2,May,pp. 264-279.

Klein, Daniel B. and Lucas, Brandon (2011)."In a Word or two, placed in the middle: The Invisible hand in Smith's Tomes", Economic Affairs,Vol.31,no.1 ,pp.43-52.

Klein, Daniel B. and Lucas, Brandon (2011)."On the Deliberate Centrality of An Invisible Hand: Reply to Gavin Kennedy, Ryan Hanley and Craig Smith" Economic Affairs, Vol.31,no.2, pp.90-92. 
Meeropol , Michael (2004). "Another Distortion of Adam Smith: The Case of the "Invisible Hand". Working Paper Series,no.79,Political Economy Research Institute, University of Massachusetts, Amherst.

Mossner EC, and Ross IS. eds.(1987) The Correspondence of Adam Smith (Glasgow Edition of the Works and Correspondence of Adam Smith) .London; Liberty Fund, Inc.

Smith, Adam.(1776).The Wealth of Nations. Modern (Cannan) Library Edition with the foreward by Max Lerner .N.Y.,N.Y. 